\title{
Identification and Confirmation of RAPD and SCAR Markers Linked to the $m s-3$ Gene Controlling Male Sterility in Melon (Cucumis melo L.)
}

\author{
Soon O. Park and Kevin M. Crosby \\ Department of Horticultural Sciences, Texas Agricultural Research and Extension Center, Texas A\&M \\ University, Weslaco, TX 78596

\begin{abstract}
Rongfeng Huang and T. Erik Mirkov
Department of Plant Pathology and Microbiology, Texas Agricultural Research and Extension Center, Texas A\&M University, Weslaco, TX 78596
\end{abstract}

\begin{abstract}
ADDITIONAL INDEX WORDS. bulked segregant analysis, randomly amplified polymorphic DNA, sequence characterized amplified region, marker-assisted backcrossing

AbSTRACT. Male sterility is an important trait of melon in $\mathbf{F}_{1}$ hybrid seed production. Molecular markers linked to a male-sterile gene would be useful in transferring male sterility into fertile melon cultivars and breeding lines. However, markers linked to the $m s-3$ gene for male sterility present in melon have not been reported. Our objectives were to identify randomly amplified polymorphic DNA (RAPD) markers linked to the $m s-3$ gene controlling male sterility using bulked segregant analysis in an $F_{2}$ population from the melon cross of line ms-3 (male-sterile) $\times$ 'TAM Dulce' (male-fertile), convert the most tightly linked RAPD marker to the $m s-3$ gene into a sequence characterized amplified region (SCAR) marker based on a specific forward and reverse 20 -mer primer pair, and confirm the linkage of the RAPD and SCAR markers with the $m s-3$ gene in an $F_{2}$ population from the cross of line $\mathrm{ms}-3 \times$ 'Mission' (male-fertile). A single recessive gene controlling male sterility was found in $F_{2}$ individuals and confirmed in $F_{3}$ families. Two RAPD markers that displayed an amplified DNA fragment in the male-sterile bulk were detected to be linked to the $m s-3$ gene in the $F_{2}$ population from the cross of line ms-3 x 'TAM Dulce'. RAPD marker OAM08.650 was closely linked to the $m s-3$ gene at $2.1 \mathrm{cM}$. SCAR marker SOAM08.644 was developed on the basis of the specific primer pair designed from the sequence of the RAPD marker OAM08.650. The linked RAPD and SCAR markers were confirmed in the $F_{2}$ population from the cross of line ms-3 $\times$ 'Mission' to be consistently linked to the $m s-3$ gene at 5.2 cM. These markers were also present in 22 heterozygous fertile $F_{1}$ plants having the $m s-3$ gene. The RAPD and SCAR markers linked to the ms-3 gene identified, and confirmed here could be utilized for backcrossing of male sterility into elite melon cultivars and lines for use as parents for $F_{1}$ hybrid seed production.
\end{abstract}

Hybrid melons are known to be higher yielding and earlier than their parental cultivars (Foster, 1967). The intensive labor demand required to make large numbers of hand pollinations is of considerable a cost in $\mathrm{F}_{1}$ hybrid seed production (Jin et al., 1998). McCreight and Elmstrom (1984) reported the high cost (12 to 30 times compared to open-pollinated cultivars) of $F_{1}$ hybrid melon seed over open-pollinated cultivars. Genic male sterility is a potentially stable and effective means to reduce such high costs by generating larger quantities of hybrid seed with less contamination and labor through insect and wind pollinations (McCreight and Elmstrom, 1984). Therefore, male sterility genes have been introgressed into fertile melon cultivars and breeding lines for use as $F_{1}$ hybrid parents (Park and Crosby, 2004).

Five single recessive genes for male sterility including $m s-1$ to $m s-5$ have been identified in melon (Bohn and Principe, 1964; Bohn and Whitaker, 1949; Lecouviour et al., 1990; McCreight and Elmstrom, 1984; Pitrat, 1991, 2002). Each of these possesses a unique phenotype (McCreight and Elmstrom, 1984; Pitrat, 1991,

Received for publication 3 Mar. 2004. Accepted for publication 13 June 2004 We acknowledge financial support from the South Texas Melon Committee. We also appreciate the constructive criticism of three reviewers, Drs. Marvin Miller, John Robinson, and Jon Jifon, Texas Agricultural Research and Extension Center, Texas A\&M Univ., to improve the manuscript. We also appreciate Dr. James D. McCreight, USDA-ARS-Salinas, for providing seeds of $m s-3$ maintainers. We also thank technicians Joe Molina, Kay Harding, and Hyun Kang, Texas A\&M Univ., for their assistance.
2002). The $m s-1$ and $m s-2$ genes are difficult to detect in the greenhouse and field, whereas the $m s-3$ gene is easily detectable with the naked eye (McCreight and Elmstrom, 1984). The $m s-4$ and $m s-5$ genes are easily observed due to male flower abortions at the bud stage (Lecouviour et al., 1990; Pitrat, 1991). No allelism was found between different male-sterile genes (Bohn and Principe, 1964; Lecouviour et al., 1990; McCreight and Elmstrom, 1984). These results were confirmed by Pitrat (1991), who reported that these sterility genes were located on five different linkage groups (LGs) of the classical melon map. McCreight (1983) and Pitrat (1991) reported loose linkages between red stem $(r)$ and the $m s-1$ gene, and between yellow green leaves $(y g)$ and the $m s-2$ gene, respectively.

Bulked segregant analysis (BSA) (Michelmore et al., 1991) is an efficient method to rapidly identify molecular markers linked to a specific gene using DNA bulks from $\mathrm{F}_{2}$ plants. This technique, along with randomly amplified polymorphic DNA (RAPD), has been used to tag quantitative genes for total soluble solids, sugars, and ascorbic acid (Park et al., 2003) as well as qualitative genes such as the dominant Fom 2 gene for resistance to fusarium wilt caused by Fusarium oxysporum Schlechtend.:Fr. f. sp. melonis W.C. Snyder \& H.N. Hans. (Wechter et al., 1995), the dominant Vat gene for resistance to cotton-melon aphid (Aphis gossypii Glover) (Klingler et al., 2001), and the recessive nsv gene for resistance to the Carmovirus melon necrotic spot virus (Morales et al., 2002) in melons. Merits of sequence characterized amplified 
region (SCAR) markers over RAPD were discussed (Paran and Michelmore, 1993). For use as a selection tool, RAPD markers linked to $D m$ genes for resistance to downy mildew caused by Bremia lactucae Regel in lettuce (Lactuca sativa L.) (Paran and Michelmore, 1993), the $M$ gene for sex expression in asparagus (Asparagus officinalis L.) (Jiang and Sink, 1997), the Fom 2 gene for resistance to Fusarium wilt in melon (Wechter et al., 1998), and the Rpfl gene for resistance to red stele root rot caused by Phytophthora fragariae Hickman var. fragariae in strawberry (Fragaria ×ananassa Duch.) (Haymes et al., 2000) have been converted into SCAR markers. Horejsi et al. (1999) and Fazio et al. (2002) also developed SCAR markers in cucumber (Cucumis sativus L.).

Introducing a male-sterile gene into fertile melon cultivars and inbred lines is a strategy recommended for facilitating $\mathrm{F}_{1}$ hybrid seed production. Molecular markers linked to a male-sterile gene would be useful in transferring the recessive allele into elite melon cultivars and inbred lines using backcrossing. Molecular tagging and mapping of male-sterile genes have been reported in tomato (Lycopersicon esculentum Mill.), soybean [Glycine max (L.) Merr.], and rice (Oryza sativa L.) (Gorman et al., 1996; Jin et al., 1998; Subudhi et al., 1997). Aarts et al. (1993) and Gorman et al. (1996) reported molecular cloning of male-sterile genes in Arabidopsis thaliana (L.) Heynh. and tomato, respectively. However, RAPD and SCAR markers linked to the $m s-3$ gene for male sterility present in melon have not been reported. Thus, a study was designed to identify RAPD markers linked to the $m s-3$ gene for male sterility using BSA in an $\mathrm{F}_{2}$ population from the melon cross of line ms-3 (male-sterile) $\times$ 'TAM Dulce' (male-fertile), and convert the most tightly linked RAPD marker to the $m s-3$ gene into a SCAR marker on the basis of a specific forward and reverse 20-mer primer pair. Park et al. (1999) emphasized the importance of confirming the marker-gene association in other populations before using molecular markers for marker-assisted selection (MAS) in breeding programs. Thus, our additional goal was to confirm the linkage of the RAPD and SCAR markers with the $m s-3$ gene in an $\mathrm{F}_{2}$ population derived from the melon cross of line ms-3 with the different fertile cultivar Mission. We then determined the presence or absence of these identified RAPD and SCAR markers in cantaloupe, honeydew, casaba, or ananas melon market class genotypes.

\section{Materials and Methods}

Plant materials. One hundred forty-one $\mathrm{F}_{2}$ plants were derived from the melon cross of line ms-3 $\times$ 'TAM Dulce' for identification of the $m s-3$ gene in a greenhouse at the Texas Agricultural Research and Extension Center (TAREC)-Weslaco of Texas A\&M Univ. in Spring 2000. The male-sterile ms-3 parent was originally noted in a single plant of PI 321005 selected from the cross of 'Georgia 47' $\times$ 'Smith's Perfect' (McCreight and Elmstrom, 1983a, 1983b, 1984). The $m s-3$ gene was chosen over other male-sterile genes because in our preliminary study it could be easily phenotyped visually. The male-fertile 'TAM Dulce' parent, a Western Shipping cantaloupe type, was developed at the TAREC-Weslaco (Kunkel, 1968). 'TAM Dulce' is resistant to powdery mildew caused by Sphaerotheca fuliginea Pollacci (races 1 and 2), downy mildew caused by Pseudoperonospora cubensis Rostovzev, and fusarium wilt (race 2). One hundred ten $\mathrm{F}_{2}$ plants were derived from the melon cross of line ms- $3 \times$ 'Mission' in the greenhouse at the TAREC-Weslaco in Winter 2001. The male-fertile 'Mission' parent, a commercial cantaloupe cultivar (Asgrow Vegetable Seeds, Oxnard, Calif.), is resistant to powdery mildew (race 1) and sulfur. We used this $\mathrm{F}_{2}$ population for confirmation of the marker-gene association.

One hundred forty-one $\mathrm{F}_{2}$ plants and $47 \mathrm{~F}_{3}$ families (18 plants per $\mathrm{F}_{3}$ ) from the cross of line ms- $3 \times$ 'TAM Dulce' were planted in the greenhouse on 20 Oct. 2000 and 18 June 2001, respectively. One hundred ten $\mathrm{F}_{2}$ plants and $58 \mathrm{~F}_{3}$ families ( 18 plants per $\mathrm{F}_{3}$ ) from the cross of line ms-3 $\times$ 'Mission' were also planted in the greenhouse on 9 Jan. 2002 and 16 July 2002, respectively. To distinguish homozygous and heterozygous fertile $\mathrm{F}_{2}$ plants, 47 and $58 \mathrm{~F}_{3}$ families were derived from randomly selected fertile $\mathrm{F}_{2}$ plants. No $\mathrm{F}_{3}$ families were derived from all male-sterile $\mathrm{F}_{2}$ plants because of their sterility. Thirty-nine melon cultivars, breeding lines, and $\mathrm{F}_{1}$ plants were planted in a completely randomized design with five replications in the greenhouse on 10 Sept. 2002. One $\mathrm{F}_{2}$ plant was grown per 11-L plastic pot containing soil-less media of Sunshine Mix \#4 (Sun Gro Horticulture, Bellevue, Wash.). Eighteen $\mathrm{F}_{3}$ plants or melon germplasm were grown per 18-cell tray containing the soil-less media of Sunshine Mix \#4. Peters 20N-8.7P-16.6K water soluble fertilizer (Scotts, Marysville, Ohio) was applied weekly. Pesticides were applied as needed to control diseases including powdery mildew and pests such as whiteflies [Bemisia tabaci (Gennadius)], spider mites (Tetranynchus urticae Koch), and aphids. Approximate day/night greenhouse temperatures were $28 \pm 3 / 23 \pm 3{ }^{\circ} \mathrm{C}$ in each experiment. Lengths of natural days/nights ranged from 10/14 to $14 / 10$ $\mathrm{h}$ in each experiment. Male sterility and fertility were checked on all plants of $\mathrm{F}_{2}, \mathrm{~F}_{3}$, and melon germplasm during flowering.

Bulked SEgregant anAlysis using RAPD. Fully expanded leaves of 141 and $110 \mathrm{~F}_{2}$ plants along with their parental pairs as well as 39 melon cultivars, breeding lines and $F_{1}$ plants were collected at $21 \mathrm{~d}$ after planting. Total genomic DNA was extracted from the leaf tissue using the method of Skroch and Nienhuis (1995). A total of 680 random 10-mer primers (Operon Technologies, Alameda, Calif.) were used for the RAPD analysis (Williams et al., 1990). Polymerase chain reactions (PCR) were performed on 96-well plates in a MJ Research thermalcycler (model PTC0100; MJ Research, Waltham, Mass.). Protocols for PCR and the composition of the final volume of reactants were same to those described by Skroch and Nienhuis (1995). A 100-base pair (bp) DNA ladder (Life Technologies, Grand Island, N.Y.) was used to estimate the length of RAPD markers. The name of each RAPD marker is derived from an "O" prefix for Operon primers, the letters identifying the Operon kit, Operon primer number, and the approximate length (bp) of the marker (Park et al., 2004).

Two different DNA bulks were prepared from equal volumes of standardized DNA $\left(10 \mathrm{ng} \cdot \mu \mathrm{L}^{-1}\right)$ from eight homozygous fertile $\mathrm{F}_{2}$ plants selected on the basis of $\mathrm{F}_{3}$ phenotypic data and eight homozygous male-sterile $\mathrm{F}_{2}$ plants, respectively. The 680 primers were used to simultaneously screen between the two different DNA bulks from male-sterile and fertile $\mathrm{F}_{2}$ plants, and between the parents line ms-3 and 'TAM Dulce'. Nine primers generated marker polymorphisms between the DNA bulks from male-sterile and fertile plants, and were subsequently tested in the $\mathrm{F}_{2}$ population derived from the cross between line ms-3 and 'TAM Dulce' for identifying the $m s-3$ gene. Two primers were tested in the $\mathrm{F}_{2}$ population of the cross line ms-3 $\times$ 'Mission' for confirming the RAPD marker-gene linkage. One primer was tested in 39 cultivars, lines, and fertile $F_{1}$ plants for determining the presence or absence of the RAPD marker most tightly linked to the $m s-3$ gene. 
CONVERTING RAPD to SCAR MARKERS. To develop a SCAR marker for the RAPD marker OAM08.650, the DNA fragment of the RAPD marker was excised and purified using the GENECLEAN II Kit (Q-BIO gene, Carlsbad, Calif.). Insertion of the purified RAPD fragment into the pCR 2.1-TOPO and cloning of the transformed plasmid were conducted using the TOPO TA Cloning Kit (Invitrogen, Carlsbad, Calif.). The cloned plasmid was harvested using the GenElute Plasmid Miniprep Kit (Sigma, St. Louis). The RAPD fragment was sequenced using the M13 reverse and forward primers at the DNA sequencing and synthesis facility of the Iowa State Univ. Office of Biotechnology, Ames. A specific forward and reverse 20-mer primer pair was designed on the basis of the forward and reverse sequences of the RAPD fragment. The forward and reverse primer pair was synthesized by Operon Technologies. Polymerase chain reactions were performed on 96-well plates in the MJ Research thermalcycler. Protocols for PCR and the composition of the final volume of reactants were same to those described by Rubio et al. (2001). The name of the SCAR marker is derived from an "S" prefix for SCAR, the original RAPD marker name except the approximate length, and the exact marker length (Park et al., 2004). The specific forward and reverse 20-mer primer pair was tested in two $\mathrm{F}_{2}$ populations of the crosses. The primer pair was also tested in 39 cultivars and lines for determining the presence or absence of the SCAR marker.

LiNKAGE ANALYSIS. To test the genetic hypothesis of a single recessive gene controlling male sterility the chi-square test was used to test goodness-of-fit to a 3:1 fertile to sterile ratio in the $\mathrm{F}_{2}$ generation or a 1:2 segregation of non-segregating for fertility and segregating for fertility and sterility in the $\mathrm{F}_{3}$ generation. To detect segregation distortion of markers, the $\mathrm{F}_{2}$ population marker data was tested for goodness-of-fit to a 3:1 ratio.

The linkage analysis of RAPD and SCAR markers with the $m s-3$ locus for male sterility was performed on the data for $\mathrm{F}_{2}$ plants of the cross line ms-3 $\times$ 'TAM Dulce' and the cross line ms-3 $\times$ 'Mission' using MAPMAKER version 3.0 (Lander et al., 1987), respectively. On the basis of a logarithm of odds (LOD) score of 3.0 and a linkage threshold of 0.4 , LGs were displayed using the Group command. For establishing a LG, a subset of markers was initially selected based on LOD scores and pairwise linkages. The best linkage order within the subset was calculated using the Compare command. LOD scores of at least 2.0 were considered different between the most and second most likely position for the marker. The Ripple command was finally used to check the marker order. Map distances [centimorgan $(\mathrm{cM})$ ] between ordered loci of marker and gene were calculated using recombination fractions and the Kosambi mapping function (Kosambi, 1944).

\section{Results and Discussion}

INHERITANCE OF MALE STERILITY. All $F_{1}$ plants derived from the melon crosses of line ms- $3 \times$ 'TAM Dulce' and line ms- $3 \times$ 'Mission' were male-fertile. A goodness-of-fit to a 3:1 ratio for the number of male-fertile to sterile $\mathrm{F}_{2}$ plants was observed in the two populations, respectively (Table 1). It was hypothesized that a single recessive gene controlled the male-sterile trait. The genetic hypothesis of a single recessive gene for the male-sterile trait was also confirmed in the $\mathrm{F}_{3}$ generation based on a satisfactory fit to a 1:2 ratio for the number of families non-segregating for male fertility and segregating for male fertility and sterility (Table 2).
A single recessive gene for the male-sterile trait found here agrees with the findings of McCreight and Elmstrom (1983a, 1983b, 1984), who reported that the male-sterile trait was controlled by a single recessive gene in four $\mathrm{F}_{2}$ populations from different melon crosses of the homozygous male-sterile ms-3 $x$ homozygous male-fertile parents. They also confirmed their result of the single recessive gene in three different testcrosses of the ms-3 parent $\times$ heterozygous fertile parents carrying the male-sterile gene. The symbols $m s-L$ and male sterile-Leesburg were assigned by McCreight and Elmstrom (1983a and 1983b) for the single recessive gene controlling male sterility. The $m s-L$ and male sterile-Leesburg were subsequently defined as $m s-3$ by McCreight and Elmstrom (1984). Four other male-sterile phenotypes have been reported in melons by investigators (Bohn and Principe, 1964; Bohn and Whitaker, 1949; Lecouviour et al., 1990; Pitrat, 1991, 2002) to be controlled by different single recessive genes such as $m s-1, m s-2, m s-4$, and $m s-5$. According to previous results obtained on the basis of allelism and linkage analyses (Lecouviour et al., 1990; McCreight and Elmstrom, 1984; Pitrat, 1991, 2002), the $m s-3$ gene is known to be independent of the other four male-sterile genes.

RAPD MARKERS LINKED TO THE MALE-STERILE GENE. A total of 680 primers were used for the RAPD analysis of two different bulks developed from male-sterile and fertile $\mathrm{F}_{2}$ plants along with their parents line ms-3 and 'TAM Dulce'. Nine RAPD markers were polymorphic in the two different DNA bulks, and displayed an amplified DNA fragment in the male-sterile bulk that was absent in the fertile bulk. An example of marker OAM08.650 is shown in Fig. 1a. These nine marker fragments segregated in the $\mathrm{F}_{2}$ population of the cross line ms-3 $\times$ 'TAM Dulce'. Of the nine markers, two were identified to be linked to the $m s-3$ gene on the basis of linkage analysis. The remaining seven markers were false positives. A goodness-of-fit to a 3:1 ratio for band presence to band absence for each of the two markers was observed in the $F_{2}$ plants (Table 3).

The integrated location of the $m s-3$ locus and the loci of two RAPD markers OAM08.650 and OAN05.800 that displayed an amplified DNA fragment in the male-sterile bulk is shown in Fig. 2. This LG included three loci spanning a length of 23.6 $\mathrm{cM}$. Marker OAM08.650 was closely linked to the $m s-3$ gene at a distance of $2.1 \mathrm{cM}$, while OAN05.800 was loosely linked to the $m s-3$ gene at $21.5 \mathrm{cM}$. No RAPD markers that displayed an amplified DNA fragment solely in the male-fertile bulk were identified in the $\mathrm{F}_{2}$ population.

RAPD markers linked to several genes for pest and disease resistance have been detected successfully by means of BSA in melons (Klingler et al., 2001; Morales et al., 2002; Wechter et al., 1995). Genes for male sterility have been tagged and mapped in horticultural and agronomic crops using different types of molecular markers (Gorman et al., 1996; Jin et al., 1998; Subudhi et al., 1997). This is the first report of molecular markers closely linked

Table 1. Chi-square analyses for segregation of male-fertile and sterile plants in two $\mathrm{F}_{2}$ populations derived from different melon crosses of line ms-3 (male-sterile) $\times$ 'TAM Dulce' (male-fertile) $(\mathrm{MT})$ and line ms-3 $\times$ 'Mission' (male-fertile) $(\mathrm{MM})$.

\begin{tabular}{lccccc}
\hline & \multicolumn{2}{c}{ No. of $\mathrm{F}_{2}$ plants } & & & \\
\cline { 2 - 5 } Cross & $\begin{array}{l}\text { Male- } \\
\text { fertile }\end{array}$ & $\begin{array}{c}\text { Male- } \\
\text { sterile }\end{array}$ & $\begin{array}{c}\text { Expected } \\
\text { ratio }\end{array}$ & $\chi^{2}$ & $P$ \\
\hline MT & 98 & 43 & $3: 1$ & 2.27 & 0.13 \\
MM & 74 & 36 & $3: 1$ & 3.50 & 0.06 \\
\hline
\end{tabular}


to the $m s-3$ gene for male sterility by means of BSA in melon.

This tight linkage of the RAPD marker OAM08.650 with the $m s-3$ gene identified here could be more useful in melon breeding than the finding of Pitrat (1991), who reported that one vegetative marker yellow green leaves $(y g)$ was linked to the $m s-2$ gene at distances of 37 and 41 $\mathrm{cM}$ in $\mathrm{F}_{2}$ and testcross populations on LG 6 in the partially classical linkage melon map consisting of 28 vegetative, floral and disease resistance markers distributed on eight LGs and five unlinked loci. Pitrat (1991) also included fusarium wilt resistance (Fom 2) on LG 6. Red stem $(r)$ was found by McCreight (1983) to be linked to the $m s-1$ gene at 11 and $25 \mathrm{cM}$ on LG 3. Subsequently, Pitrat (1991) found two additional markers pale green foliage $(P a)$ and glabrous $(g l)$ on the same LG.

According to the results of Pitrat (1991 and 2002), the other malesterile genes $m s-3, m s-4$, and $m s-5$ were independently located on LGs 10,11 , and 12 of their classical map. Molecular genetic linkage maps of melon constructed on the basis of various types of molecular markers such as isozyme, RAPD, RFLP, simple sequence repeat(SSR), amplified fragment length polymorphism, and resistance gene homologues have been reported (Baudracco-Arnas and Pitrat, 1996; Brotman et al., 2000; Danin-Poleg et al., 2000, 2002; Oliver et al., 2001; Perin et al., 2002; Wang et al., 1997). Due to different parental genotypes and genetic markers, few common phenotypic or SSR markers that were connected among linkage maps, were found (Danin-Poleg et al., 2001; Pitrat, 2002) and thus, no saturated reference melon map is currently available. The male-sterile $m s-2$ gene was included in the molecular maps. The two RAPD markers linked to the $m s-3$ gene were not included in the published melon maps.

DEVELOPMENT OF A SCAR MARKER LINKED TO THE MALESTERILE GENE. The RAPD marker OAM08.650 was converted into a SCAR marker on the basis of the specific forward and reverse 20-mer primer pair. The exact length of the RAPD fragment OAM08.650 was 644 bp based on the sequence data (not shown). The sequence of the forward 20-mer primer was 5'ACCACGAGTGTCGAGAAGAA-3', while that of the reverse 20-mer primer was 5'-ACCACGAGTGAGGGATCTTC-3'. The underlined sequences were the original 10 -mer sequence of the OAM08 primer. Melting temperatures of the forward and reverse primers were $61^{\circ} \mathrm{C}$ and $63^{\circ} \mathrm{C}$, respectively. We used $65^{\circ} \mathrm{C}$ as a consensus annealing temperature. (male-fertile) (MM). able 2. Chi-square analyses for segregation of nonsegregating for male-fertile and segregating for male-fertile and sterile in 47 and $58 \mathrm{~F}_{3}$ families derived from two different melon crosses

\begin{tabular}{|c|c|c|c|c|c|}
\hline \multirow[b]{2}{*}{ Cross } & \multicolumn{2}{|c|}{ No. of $\mathrm{F}_{3}$ families } & \multirow[b]{2}{*}{$\begin{array}{l}\text { Expected } \\
\text { ratio }\end{array}$} & \multirow[b]{2}{*}{$\chi^{2}$} & \multirow[b]{2}{*}{$P$} \\
\hline & $\begin{array}{l}\text { Nonsegregating } \\
\text { for male-fertile }\end{array}$ & $\begin{array}{c}\text { Segregating for } \\
\text { male-fertile and sterile }\end{array}$ & & & \\
\hline$\overline{\mathrm{MT}}$ & 14 & 33 & $1: 2$ & 0.27 & 0.61 \\
\hline MM & 14 & 44 & $1: 2$ & 2.21 & 0.14 \\
\hline
\end{tabular}

Table 3. Chi-square analyses for segregation of RAPD and SCAR fragments for three and two markers linked to the $m s-3$ gene controlling male sterility in two $\mathrm{F}_{2}$ populations derived from the different melon crosses, line ms-3 (male-sterile) $\times$ 'TAM Dulce' (male-fertile) (MT) and line ms-3 $\times$ 'Mission' (male-fertile) (MM).

\begin{tabular}{|c|c|c|c|c|c|c|c|c|}
\hline \multirow[b]{2}{*}{ Cross } & \multicolumn{3}{|c|}{ Molecular marker } & \multicolumn{2}{|c|}{ No. of $F_{2}$ plants } & \multirow[b]{2}{*}{ Ratio } & \multirow[b]{2}{*}{$\chi^{2}$} & \multirow[b]{2}{*}{$P$} \\
\hline & Name & Type & Source & Presence & Absence & & & \\
\hline$\overline{\mathrm{MT}}$ & OAM08.650 & RAPD & ms-3 & 74 & 16 & $3: 1$ & 2.12 & 0.14 \\
\hline MT & SOAM08.644 & SCAR & $\mathrm{ms}-3$ & 74 & 16 & $3: 1$ & 2.12 & 0.14 \\
\hline MT & OAN05.800 & RAPD & $\mathrm{ms}-3$ & 72 & 18 & $3: 1$ & 0.95 & 0.33 \\
\hline MM & OAM08.650 & RAPD & $\mathrm{ms}-3$ & 78 & 16 & $3: 1$ & 2.79 & 0.10 \\
\hline MM & SOAM08.644 & SCAR & $\mathrm{ms}-3$ & 78 & 16 & 3:1 & 2.79 & 0.10 \\
\hline
\end{tabular}
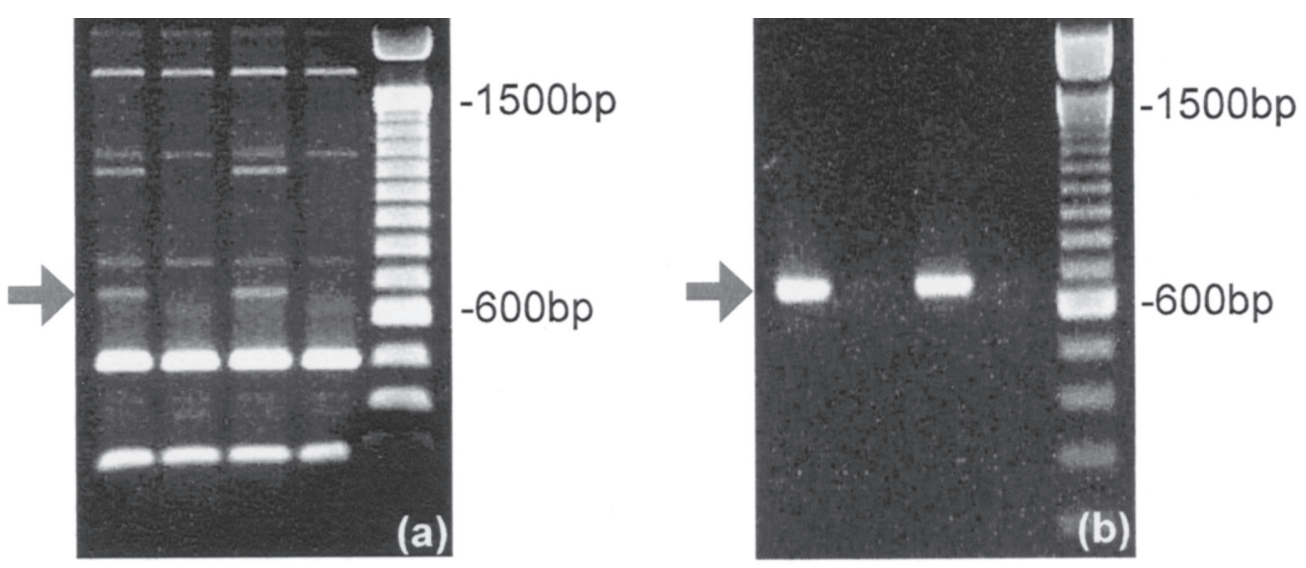

g. 1. (a) RAPD marker OAM08.650 and (b) SCAR marker SOAM08.644 amplified with the specific primer pair designed from the sequence of the RAPD marker OAM08.650 expressing polymorphism between two DNA bulks from male-sterile and fertile $\mathrm{F}_{2}$ plants, and between the male-sterile parent line ms-3 and the male-fertile parent 'TAM Dulce'. 1 = line ms-3, 2 = 'TAM Dulce', 3 = DNA bulk from eight male-sterile $\mathrm{F}_{2}$ plants, 4 = DNA bulk from eight male-fertile $\mathrm{F}_{2}$ plants, and 5 = a 100-bp DNA marker ladder.

The resulting SCAR marker SOAM08.644, shown in Fig. 1b, was present in line ms-3 and the DNA bulk from male-sterile $\mathrm{F}_{2}$ plants, and absent in 'TAM Dulce' and the DNA bulk from male-fertile $F_{2}$ plants. The SCAR marker segregated in the $F_{2}$ population of the cross line ms- $3 \times$ 'TAM Dulce'. A goodnessof-fit to a 3:1 ratio for band presence to band absence for the marker SOAM08.644 was observed in the $F_{2}$ (Table 3). The LG developed using the male-sterile locus and the marker loci including the SCAR is shown in Fig. 2. The marker SOAM08.644 showed no recombination with the marker OAM08.650 in the $\mathrm{F}_{2}$ population, and thus, the SCAR and RAPD markers were observed at the same locus on the LG. The marker SOAM08.644 was also closely linked to the $m s-3$ gene at $2.1 \mathrm{cM}$. This is the first report on development of a SCAR marker linked to the $m s-3$ gene in melon.

Confirmation of the marker-gene linkage. Confirmation of the tight linkage of the RAPD OAM08.650 and SCAR 
SOAM08.644 markers with the $m s-3$ gene identified in the $\mathrm{F}_{2}$ population of the cross line ms- $3 \times$ 'TAM Dulce' was needed in other populations to substantiate their merit in melon breeding. Of the three RAPD and SCAR markers linked to the $m s-3$ gene identified in the original $\mathrm{F}_{2}$ population, OAM08.650 and SOAM08.644 were polymorphic between line ms-3 and 'Mission'. These two markers, tightly linked to the $m s-3$ gene in the original $\mathrm{F}_{2}$ population, were present in the line ms-3 parent, and absent in the 'Mission' parent. A 3:1 goodness-of-fit ratio for band presence to band absence for each of the RAPD and SCAR markers was observed in the $\mathrm{F}_{2}$ population of the cross line $\mathrm{ms}-3 \times$ 'Mission' (Table 3).

The LG containing the RAPD and Fig. SCAR markers as well as the $m s-3$ gene developed using the $\mathrm{F}_{2}$ population from the cross of line ms-3 $\times$ 'Mission' is shown in Fig. 2. No recombination between the RAPD and SCAR markers was observed in the population, indicating that both were noted at the same marker locus. The RAPD OAM08.650 and SCAR SOAM08.644 markers were confirmed in the $\mathrm{F}_{2}$ population from the cross of ms-3 with the fertile cultivar Mission to be consistently linked to the $m s-3$ gene at a distance of $5.2 \mathrm{cM}$ (Fig. 2). Different linkage distances were estimated between the gene and the markers in two $\mathrm{F}_{2}$ populations. These differences may result from sampling variation in markers which can create variations in distances between the gene and the markers. Also, different recombination frequencies and chromosomal differences can contribute to such observed differences. The RAPD marker OAN05.800, very loosely linked to the $m s-3$ gene detected in the original $\mathrm{F}_{2}$ population, was not confirmed in this genetic population.

The andromonoecious gene $(a)$ regulating stamen absence or stamen presence in female flowers was found to be unlinked to the $m s-3$ gene in the $\mathrm{F}_{2}$ population from the cross of line ms- $3 \times$ 'Mission'. No linkage between the $a$ and the $m s-3$ genes found here confirms the findings of Pitrat (1991 and 2002), who reported that the andromonoecious gene on LG 4 was not associated with the other four male-sterile genes as well as the $m s-3$ gene.

Our confirmation of the marker-gene association in two different populations is an essential step for universal use of these linked markers in MAS in breeding programs, as suggested by Park et al. (1999). They confirmed that RAPD markers and flower color were consistently and significantly associated with major genes affecting resistance to common bacterial blight, incited by Xanthomonas campestris pv. phaseoli (Smith) Dye, in three different genetic backgrounds including recombinant inbred (RI), backcross, and $\mathrm{F}_{2}$ populations of different crosses. Therefore, the RAPD and SCAR markers linked to the $m s-3$ gene identified and confirmed in two segregating populations here should be more reliable for backcrossing the gene into inbred lines than those evaluated in a single population.

SURVEY OF LINKED RAPD AND SCAR MARKERS IN DIVERSE MELON GERMPLASM. We investigated the presence or absence of the markers OAM08.650 and SOAM08.644 linked to the recessive $m s-3$ gene in 39 cantaloupe, honeydew, casaba or ananas melon cultivars, breeding lines, and $F_{1}$ plants (Table 4). These melon germplasm with or without the sterility allele were observed to be male-fertile, except $m s-3 / m s-3$ genotype. Of the fertile melon germplasm, 16 cultivars and lines lacking the sterile gene were homozygous fertile, whereas all $\mathrm{F}_{1}$ plants having the recessive gene, derived from 22 different crosses of line ms-3 with homozygous fertile cultivars and lines mainly cantaloupe types, were heterozygous fertile. The presence of the RAPD and SCAR markers was consistently associated with all heterozygous fertile $F_{1}$ plants carrying the $m s-3$ gene. However, all homozygous fertile cultivars and lines without the gene lacked the RAPD and SCAR marker fragments linked to the $m s-3$ gene. These results would be expected due to the tight linkage of the RAPD and SCAR markers with the $m s-3$ gene. Therefore, the RAPD and SCAR markers could be used to expedite the transfer of this sterility gene into cantaloupe, honeydew, casaba or ananas cultivars and lines using marker-assisted backcrossing (MAB).

Cultivars and inbred lines having the male-sterile gene can be utilized as parents to produce $\mathrm{F}_{1}$ hybrid seeds. However, there is a major constraint in the use of male sterility for this purpose. Due to the single recessive nature of the $m s-3$ gene, homozygous sterile plants can only be found in segregating populations. Twenty-five percent of an $\mathrm{F}_{2}$ population are homozygous sterile plants, while $50 \%$ are sterile in a heterozygote backcross to a homozygous sterile plant. Homozygous and heterozygous fertile plants are indistinguishable, especially in populations developed by the backcross method for the transfer of the sterility gene into cultivars and lines. Progeny testing via self-pollination is a desirable way to identify heterozygous fertile plants. The use of markers tightly linked to the $m s-3$ gene, displaying an amplified DNA fragment in the sterile bulk, is of special interest to breeders because it can be employed to easily distinguish between homozygous and heterozygous fertile plants in backcross populations without progeny testing. In a heterozygote backcross to a homozygous fertile plant the presence of the markers is associated with heterozygous 
Table 4. Presence (+) or absence (-) of RAPD marker OAM08.650 and SCAR marker SOAM08.644 tightly linked to the $m s-3$ gene controlling male sterility in homozygous fertile $(\mathrm{HF})$, heterozygous fertile $(\mathrm{HeF})$, or homozygous sterile (HS) melon cultivars, breeding lines, and $\mathrm{F}_{1}$ plants with or without the male-sterile allele.

\begin{tabular}{|c|c|c|c|c|c|}
\hline \multicolumn{2}{|c|}{ Melon cultivar, breeding line, and $\mathrm{F}_{1}$} & \multirow[b]{2}{*}{ Phenotype } & \multirow[b]{2}{*}{ Genotype } & \multicolumn{2}{|c|}{ RAPD and SCAR markers } \\
\hline Entry & Type & & & OAM08.650 & SOAM08.644 \\
\hline ms-3 & Cantaloupe & Sterile & HS & + & + \\
\hline 'TAM Dulce' & Cantaloupe & Fertile & $\mathrm{HF}$ & - & - \\
\hline 'TAM Uvalde' & Cantaloupe & Fertile & $\mathrm{HF}$ & - & - \\
\hline 'TAM Perlita' & Cantaloupe & Fertile & $\mathrm{HF}$ & - & - \\
\hline 'Mission' & Cantaloupe & Fertile & $\mathrm{HF}$ & - & - \\
\hline 'Durango' & Cantaloupe & Fertile & $\mathrm{HF}$ & - & - \\
\hline 'Primo' & Cantaloupe & Fertile & $\mathrm{HF}$ & - & - \\
\hline 'Wescan' & Cantaloupe & Fertile & $\mathrm{HF}$ & - & - \\
\hline 'Rio Gold' & Cantaloupe & Fertile & $\mathrm{HF}$ & - & - \\
\hline Breeding line 1405 & Cantaloupe & Fertile & $\mathrm{HF}$ & - & - \\
\hline Breeding line $1405 \mathrm{gl}$ & Cantaloupe & Fertile & $\mathrm{HF}$ & - & - \\
\hline Breeding line 1405 PMR & Cantaloupe & Fertile & $\mathrm{HF}$ & - & - \\
\hline Breeding line 1409 & Cantaloupe & Fertile & $\mathrm{HF}$ & - & - \\
\hline 'TAM Dew Improved (TDI)' & Honeydew & Fertile & $\mathrm{HF}$ & - & - \\
\hline 'TAM Mayan Sweet (TMS)' & Casaba & Fertile & $\mathrm{HF}$ & - & - \\
\hline 'Deltex' & Ananas & Fertile & $\mathrm{HF}$ & - & - \\
\hline TGR1551 & Agrestis & Fertile & $\mathrm{HF}$ & - & - \\
\hline $\mathrm{F}_{1}$ from ms-3 $\times$ 'TAM Dulce' & Cantaloupe & Fertile & $\mathrm{HeF}$ & + & + \\
\hline $\mathrm{F}_{1}$ from ms-3 $\times$ 'TAM Uvalde' & Cantaloupe & Fertile & $\mathrm{HeF}$ & + & + \\
\hline $\mathrm{F}_{1}$ from ms-3 $\times$ 'TAM Perlita' & Cantaloupe & Fertile & $\mathrm{HeF}$ & + & + \\
\hline $\mathrm{F}_{1}$ from ms-3 $\times$ 'Mission' & Cantaloupe & Fertile & $\mathrm{HeF}$ & + & + \\
\hline $\mathrm{F}_{1}$ from ms-3 $\times$ 'Durango' & Cantaloupe & Fertile & $\mathrm{HeF}$ & + & + \\
\hline $\mathrm{F}_{1}$ from ms-3 $\times$ 'Primo' & Cantaloupe & Fertile & $\mathrm{HeF}$ & + & + \\
\hline$F_{1}$ from ms-3 $\times$ 'Wescan' & Cantaloupe & Fertile & $\mathrm{HeF}$ & + & + \\
\hline $\mathrm{F}_{1}$ from ms-3 $\times$ 'Rio Gold' & Cantaloupe & Fertile & $\mathrm{HeF}$ & + & + \\
\hline $\mathrm{F}_{1}$ from ms-3 $\times 1405$ & Cantaloupe & Fertile & $\mathrm{HeF}$ & + & + \\
\hline $\mathrm{F}_{1}$ from $\mathrm{ms}-3 \times 1405 \mathrm{gl}$ & Cantaloupe & Fertile & $\mathrm{HeF}$ & + & + \\
\hline $\mathrm{F}_{1}$ from ms-3 $\times 1405 \mathrm{PMR}$ & Cantaloupe & Fertile & $\mathrm{HeF}$ & + & + \\
\hline $\mathrm{F}_{1}$ from $\mathrm{ms}-3 \times 1409$ & Cantaloupe & Fertile & $\mathrm{HeF}$ & + & + \\
\hline $\mathrm{F}_{1}$ from ms-3 $\times$ 'TDI' & Honeydew & Fertile & $\mathrm{HeF}$ & + & + \\
\hline $\mathrm{F}_{1}$ from ms-3 $\times$ 'TMS' & Casaba & Fertile & $\mathrm{HeF}$ & + & + \\
\hline $\mathrm{F}_{1}$ from ms-3 $\times$ 'Deltex' & Mixed & Fertile & $\mathrm{HeF}$ & + & + \\
\hline $\mathrm{F}_{1}$ from ms-3 $\times$ TGR 1551 & Mixed & Fertile & $\mathrm{HeF}$ & + & + \\
\hline $\mathrm{F}_{1}$ from ms-3 $\times$ MM-44 & Cantaloupe & Fertile & $\mathrm{HeF}$ & + & + \\
\hline $\mathrm{F}_{1}$ from $\mathrm{ms}-3 \times \mathrm{MM}-46$ & Cantaloupe & Fertile & $\mathrm{HeF}$ & + & + \\
\hline $\mathrm{F}_{1}$ from ms-3 $\times$ MM-66 & Cantaloupe & Fertile & $\mathrm{HeF}$ & + & + \\
\hline $\mathrm{F}_{1}$ from ms-3 $\times$ MM- 67 & Cantaloupe & Fertile & $\mathrm{HeF}$ & + & + \\
\hline $\mathrm{F}_{1}$ from $\mathrm{ms}-3 \times \mathrm{MM}-73$ & Cantaloupe & Fertile & $\mathrm{HeF}$ & + & + \\
\hline $\mathrm{F}_{1}$ from $\mathrm{ms}-3 \times \mathrm{MM}-76$ & Cantaloupe & Fertile & $\mathrm{HeF}$ & + & + \\
\hline
\end{tabular}

fertile plants, whereas the absence of the markers is associated with homozygous fertile plants. Also, $50 \%$ of the plants (homozygous fertile) in the backcross and RI populations, and 25\% of the plants in an $\mathrm{F}_{2}$ population can be discarded at early growth stages. This reduction of population size is crucial to breeders who are faced with rental costs or limitation of greenhouse space for screening plants. These RAPD and SCAR markers tightly linked to the $m s-3$ gene, identified and confirmed here, will allow the rapid transfer of the male-sterile gene into cultivars and lines using $\mathrm{MAB}$ without progeny testing.

\section{Literature Cited}

Aarts, M.G.M., W.G. Dirkse, W.J. Steikema, and A. Pereira. 1993. Transposon tagging of a male sterility gene in Arabidopsis. Nature 363:715-717.

Baudracco-Arnas, S. and M. Pitrat. 1996. A genetic map of melon $(\mathrm{Cu}$ - cumis melo L.) with RFLP, RAPD, isozyme, disease resistance and morphological markers. Theor. Appl. Genet. 93:57-64.

Bohn, G.W. and J.A. Principe. 1964. A second male-sterility gene in the muskmelon. J. Hered. 55:211-215.

Bohn, G.W. and T.W. Whitaker. 1949. Agene for male sterility in the muskmelon (Cucumis melo L.). Proc. Amer. Soc. Hort. Sci. 53:309-314.

Brotman, Y., L. Silberstein, I. Kovalski, J. Klingler, G. Thompson, N. Katzir, and R. Perl-Treves. 2000. Linkage groups of Cucumis melo, including resistance gene homologues and known genes. Acta Hort. 510:441-448.

Danin-Poleg, Y., N. Reis, G. Tzuri, and N. Katzir. 2001. Development and characterization of microsatellite markers in Cucumis. Theor. Appl. Genet. 102:61-72.

Danin-Poleg, Y., N. Reis, S. Baudracco-Arnas, M. Pitrat, J.E. Staub, M. Oliver, P. Arús, C.M. de Vicente, and N. Katzir. 2000. Simple sequence repeats in Cucumis mapping and map merging. Genome 43:963-974.

Danin-Poleg, Y., Y. Tadmor, G. Tzuri, N. Reis, J. Hirschberg, and N. 
Katzir. 2002. Construction of a genetic map of melon with molecular markers and horticultural traits, and localization of genes associated with ZYMV resistance. Euphytica 125:373-384.

Fazio, G., J.E. Staub, and S.M. Chung. 2002. Development and characterization of PCR markers in cucumber. J. Amer. Soc. Hort. Sci. 127:545-557.

Foster, R.E. 1967. $F_{1}$ hybrid muskmelons, I. Superior performance of selected hybrids. Proc. Amer. Soc. Hort. Sci. 91:390-395.

Gorman, S.W., D. Banasiak, C. Fairley, and S. McCormick. 1996. A 610 $\mathrm{kb}$ YAC clone harbors $7 \mathrm{cM}$ of tomato (Lycopersicon esculentum) DNA that includes the male sterile 14 gene and a hotspot for recombination. Mol. General Genet. 251:52-59.

Haymes, K.M., W.E. Van de Weg, P. Arens. J.L. Maas, B. Vosman, and A.P.M. Den Nijs. 2000. Development of SCAR markers linked to a Phytophthora fragariae resistance gene and their assessment in European and North American strawberry genotypes. J. Amer. Soc. Hort. Sci. 125:330-339.

Horejsi, T., J.M. Box, and J.E. Staub. 1999. Efficiency of randomly amplified polymorphic DNA to sequence characterized amplified region marker conversion and their comparative polymerase chain reaction sensitivity in cucumber. J. Amer. Soc. Hort. Sci. 124:128-135.

Jiang, C. and K.C. Sink. 1997. RAPD and SCAR markers linked to the sex expression locus $M$ in asparagus. Euphytica 94:329-333.

Jin, W., R.G. Palmer, H.T. Horner, and R.C. Shoemaker. 1998. Molecular mapping of a male-sterile gene in soybean. Crop Sci. 38:1681-1685.

Klingler, J., I. Kovalski, L. Silberstein, G.A. Thompson, and R. PerlTreves. 2001. Mapping of cotton-melon aphid resistance in melon. J. Amer. Soc. Hort. Sci. 126:56-63.

Kosambi, D.D. 1944. The estimation of map distances from recombination values. Ann. Eugenics 12:172-175.

Kunkel, H.O. 1968. Dulce cantaloupe. Texas Agr. Expt. Sta. Bul. L-760, Texas A\&M Univ., College Station.

Lander,E.S., P. Green, J.Abrahamson, A. Barlow, M.J. Daly, S.E. Lincoln, and L. Newburg. 1987. MAPMAKER: An interactive computer package for constructing primary genetic linkage maps with experimental and natural populations. Genomics 1:174-181.

Lecouviour, M., M. Pitrat, and G. Risser. 1990. A fifth gene for male sterility in Cucumis melo. Cucurbit Genet. Coop. Rpt. 13:34-35.

McCreight, J.D. 1983. Linkage of red stem and male sterile-1 in muskmelon. Cucurbit Genet. Coop. Rpt. 6:48.

McCreight, J.D. and G.W. Elmstrom. 1983a. A third male sterile gene in muskmelon. Cucurbit Genet. Coop. Rpt. 6:46.

McCreight, J.D. and G.W. Elmstrom. 1983b. Male sterile-Leesburg: The third muskmelon male sterile gene. HortScience 18:564.

McCreight, J.D. and G.W. Elmstrom. 1984. A third muskmelon malesterile gene. HortScience 19:268-270.

Michelmore, R.W., I. Paran, and R.V. Kesseli. 1991. Identification of markers linked to disease resistance genes by bulked segregant analysis: A rapid method to detect markers in specific genomic regions using segregating populations. Proc. Natl. Acad. Sci. USA 88:9828-9832.

Morales, M., M. Luis-Arteaga, J.M. Alvarez, R. Dolcet-Sanjuan, A. Monfort, P. Arus, and J. Garcia-Mas. 2002. Marker saturation of the region flanking the gene $N S V$ conferring resistance to the melon necrotic spot Carmovirus (MNSV) in melon. J. Amer. Soc. Hort. Sci. 127:540-544.

Oliver, M., J. Garcia-Mas, M. Cardús, N. Pueyo, A.I. López-Sesé, M. Arroyo, H. Gómez-Paniagua, P.Arús, and M.C. de Vicente. 2001. Construction of a reference linkage map for melon. Genome 44:836-845.

Paran, I. and R.W. Michelmore. 1993. Development of reliable PCRbased markers linked to downy mildew resistance genes in lettuce. Theor. Appl. Genet. 85:985-993.

Park, S.O., D.P. Coyne, J.R. Steadman, K.M. Crosby, and M.A. Brick. 2004. RAPD and SCAR markers linked to the Ur-6 Andean gene controlling specific rust resistance in common bean. Crop Sci. 44:1799-1807.

Park, S.O., D.P. Coyne, N. Mutlu, G. Jung, and J.R. Steadman. 1999. Confirmation of molecular markers and flower color associated with QTL for resistance to common bacterial blight in common beans. J. Amer. Soc. Hort. Sci. 124:519-526.

Park, S.O., J.W. Sinclair, K.S. Yoo, L.M. Pike, and K.M. Crosby. 2003. Detection of QTL for total soluble solids, sugars, and vitamin C in cantaloupe melon. HortScience 38:676.

Park, S.O. and K.M. Crosby. 2004. Identification of RAPD markers linked to the male-sterile $m s-3$ gene in melon. Acta Hort. 637:243-249.

Perin, C., L.S. Hagen, V. de Conto, N. Katzir, Y. Danin-Poleg, V. Portnoy, S. Baudracco-Arnas, J. Chadoeuf, C. Dogimont, and M. Pitrat. 2002. A reference map of Cucumis melo based on two recombinant inbred line populations. Theor. Appl. Genet. 104:1017-1034.

Pitrat, M. 1991. Linkage groups in Cucumis melo L. J. Hered. 82:406411.

Pitrat, M. 2002. 2002 gene list for melon. Cucurbit Genet. Coop. Rpt. 25:76-93.

Rubio, L., Y. Abou-Jawdah, H.X. Lin, and B.W. Falk. 2001. Geographically distant isolates of the crinivirus cucurbit yellow stunting disorder virus show very low genetic diversity in the coat protein gene. J. General Virology 82:929-933.

Skroch, P.W. and J. Nienhuis. 1995. Qualitative and quantitative characterization of RAPD variation among snap bean genotypes. Theor. Appl. Genet. 91:1078-1085.

Subudhi, P.K., R.P. Borkakati, S.S. Virmani, and N. Huang. 1997. Molecular mapping of a thermosensitive genetic male sterility gene in rice using bulked segregant analysis. Genome 40:188-194.

Wang, Y.H., C.E. Thomas, and R.A. Dean. 1997. A genetic map of melon (Cucumis melo L.) based on amplified fragment length polymorphism (AFLP) markers. Theor. Appl. Genet. 95:791-798.

Wechter, W.P., M.P. Whitehead, C.E. Thomas, and R.A. Dean. 1995. Identification of a randomly amplified polymorphic DNA marker linked to the Fom 2 fusarium wilt resistance gene in muskmelon MR1. Phytopathology 85:1245-1249.

Wechter, W.P., R.A. Dean, and C.E. Thomas. 1998. Development of sequence-specific primers that amplify a $1.5-\mathrm{kb}$ DNA marker for race 1 fusarium wilt resistance in Cucumis melo L. HortScience $33: 291-292$.

Williams, J.G.K.,A.R. Kubelik, K.J.Livak, J.A. Rafalksi, and S.V. Tingey. 1990. DNA polymorphisms amplified by arbitrary primers are useful as genetic markers. Nucl. Acids Res. 18:6531-6535. 